\title{
IMPLEMENTASI PRINSIP DAN PROSEDUR PENGELOLAAN KEUANGAN SEKOLAH DI SMA MUHAMMADIYAH 1 PALEMBANG
}

\author{
${ }^{1}$ Fatra dan ${ }^{2}$ Edi Harapan \\ ${ }^{1}$ SMA Muhammadiyah 1 Palembang \\ ${ }^{2}$ Dosen Program Studi Magister Manajemen Pendidikan, Universitas PGRI Palembang \\ e-mail: fatrapps.fihir@gmail.com
}

\begin{abstract}
The objectives of this research were 1) describing the funding of educational resources in High School Muhammadiyah 1 Palembang; 2) describing the realization and allocation the funding in High School Muhammadiyah 1 Palembang; and 3) describing the characteristics of accountability the funding in High School Muhammadiyah 1 Palembang. This research was qualitative. We studied the problems not to prove neither to reject the hypothesis that was made in the past nor to process data and analyze problem in non-numerically. Sources of income in High School Muhammadiyah 1 Palembang listed on Budget Plan (RAPBS). The sources were come from APBN, APBD of Province, and APBD of Palembang. The allocation of funds generally used to make equalization in education and conducted to improve the quality of education. Financial accountability was created by treasurer and principal and it was known by the school committee monthly, including the supporting data, proves of expense and details of expense.
\end{abstract}

Keyword: Finance, Principle and Procedure of Management, High School Muhammadiyah 1 Palembang.

\section{PENDAHULUAN}

Upaya pengelolaan pembiayaan di SMA Muhammadiyah 1 Palembang dilakukan dengan dan berprinsip pada transparansi, akuntabilitas, efisien dan efektif. Berdasarkan pengamatan di lapangan diketahui bahwa kepala sekolah dan guru menyadari sepenuhnya bahwa biaya pendidikan mempunyai peran yang sangat penting dan menentukan kegiatan pembelajaran. Hampir semua kegiatan membutuhkan biaya sehingga dapat dikatakan tanpa biaya, proses pendidikan di SMA Muhammadiyah 1 Palembang tidak berdaya sama sekali. Biaya yang diperlukan untuk menunjang kegiatan pendidikan di SMA Muhammadiyah 1 Palembang memiliki cakupan yang luas yakni semua jenis pengeluaran yang berkenaan dengan penyelenggaraan pendidikan, baik dalam bentuk uang, barang ataupun tenaga (yag dapat dihargai dengan uang).

Menurut amanat UU Nomor 20 tahun 2003, tentang Sistem Pendidikan Nasional, pasal 51 (1) yang menyatakan, "Pengelolaan satuan pendidikan anak usia dini, pendidikan dasar, dan pendidikan menengah dilaksanakan berdasarkan standart pelayanan minimal dengan prinsip pengelolaan berbasis sekolah/madrasah" dan pasal 48 (1) yang menyatakan "Pengelolaan dana pendidikan berdasarkan pada prinsip keadilan, efisiensi, transparansi, dan akuntabilitas publik". 
Prinsip pengelolaan sekolah/madrasah yang baik ditandai dengan adanya partisipasi aktif warga sekolah/madrasah dan stakeholders dalam pengambilan keputusan, transparansi, dan akuntabilitas dalam pengelolaan keuangan sekolah/madrasah. Saat ini pengelolaan sekolah/ madrasah sudah bersifat otonomi. Ini terjadi setelah sekolah menerapkan prinsip Pengelolaan Berbasis Sekolah (MBS) yang bertujuan untuk meningkatkan mutu proses dan hasil pendidikan. MBS, melalui tiga pilar secara holistik, yaitu pengelolaan sekolah/ madrasah, pembelajaran yang aktif, kreatif, efektif dan menyenangkan (PAKEM) dan peningkatan Peran Serta Masyarakat (PSM) diharapkan dapat meningkatkan mutu proses dan hasil pendidikan.

Pendidikan tidak terlepas dari kebutuhan dana untuk mendukung terselenggaranya program pendidikan secara efektif dan efisien. Campbell dkk. (1983) mengemukakan penyelenggaraan pendidikan di sekolah dalam segala aktivitasnya memerlukan sarana dan prasarana untuk proses pembelajaran, layanan, pelaksanaan program supervisi, penggajian, dan kesejahteraan para guru dan staf lainnya, kesemuanya itu memerlukan anggaran dan keuangan.

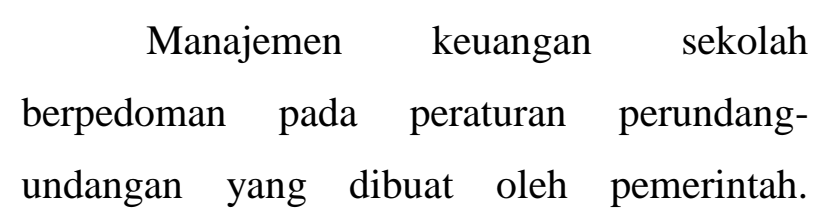

Peraturan tersebut harus dipedomani sekolah dalam menyelenggarakan pendidikan termasuk pengelolaan keuangan. Tujuan dari peraturan tersebut adalah agar pendidikan memiliki arah dalam penyelenggaraannya, dapat dipertanggungjawabkan penyelenggaraan pendidikan kepada publik, meningkatkan pelayanan efektif dan efisien bidang pendidikan, dan peningkatan kepastian hukum termasuk pembenahan koordinasi terhadap peraturan daerah dan pusat. Penyelenggaraan pendidikan berpedoman pada SNP yang berfungsi sebagai dasar dalam perencanaan, pelaksanaan, dan pengawasan pendidikan dalam rangka mewujudkan pendidikan nasional yang bermutu.

Tujuan penelitian ini adalah 1) untuk mendeskripsikan sumber-sumber dana pendidikan di SMA Muhammadiyah 1 Palembang; 2) untuk mendeskripsikan alokasi dan realisasi pembiayaan pendidikan di SMA Muhammadiyah 1 Palembang; dan 3) untuk mendeskripsikan karakteristik pertanggung jawaban dana pendidikan di SMA Muhammadiyah 1 Palembang.

\section{KONSEP DASAR PENGELOLAAN KEUANGAN SEKOLAH}

Pengelolaan keuangan dapat diartikan sebagai tindakan pengurusan/ketatausahaan keuangan yang meliputi pencatatan, perencanaan, pelaksanaan, pertanggung 
jawaban,dan pelaporan (Depdiknas Ditjen Dikdasmen, 2007). Menurut Kristiawan, dkk (2017) upaya mengumpulkan dana untuk membiayai operasional dan pengembangan pendidikan, untuk meningkatkan kualitas SDM, sehingga mampu bekerjasama di lingkup lokal, regional, nasional, maupun internasional. Dengan demikian, pengelolaan keuangan sekolah merupakan rangkaian aktivitas mengatur keuangan sekolah mulai dari perencanaan, pembukuan, pembelanjaan, pengawasan, dan pertanggungjawaban keuangan sekolah. Beberapa kegiatan pengelolaan keuangan yaitu memperoleh dan menetapkan sumber-sumber pendanaan, pemanfaatan dana pelaporan, pemeriksaan, dan pertanggungjawaban (Lipham, 1985; Keith, 1991). Dalam pengelolaan keuangan sekolah terdapat rangkaian aktivitas yang terdiri dari perencanaan program sekolah, perkiraan pemasukan dan pengeluaran dalam pelaksanaan program, pengesahan, dan penggunaan anggaran sekolah.

Melalui kegiatan pengelolaan keuangan, kebutuhan pendanaan kegiatan sekolah dapat direncanakan, diupayakan pengadaannya, dibukukan secara transparan, dan digunakan untuk membiayai pelaksanaan program sekolah secara efektif dan efisien. Oleh karena itu, tujuan pengelolaan keuangan adalah:1) meningkatkan keefektifan dan efisiensi penggunaan keuangan sekolah/ madrasah, 2) meningkatkan akuntabilitas dan transparansi keuangan sekolah/ madrasah, 3) meminimalkan penyalahgunaan anggaran sekolah/madrasah.

Untuk mencapai tujuan tersebut dibutuhkan kreativitas kepala sekolah/ madrasah dalam menggali sumber-sumber dana, menempatkan bendaharawan yang menguasai dalam pembukuan dan pertanggungjawaban keuangan, serta memanfaatkannya secara benar sesuai peraturan perundangan yang berlaku.

\section{PRINSIP - PRINSIP PENGELOLAAN KEUANGAN SEKOLAH}

Pengelolaan

keuangan

sekolah/madrasah perlu memperhatikan sejumlah prinsip. Undang - Undang Nomor 20 Tahun 2003 pasal 48 menyatakan bahwa pengelolaan dana pendidikan berdasarkan pada prinsip keadilan, efisiensi, transparansi, dan akuntabilitas publik (Kristiawan, dkk. 2017). Disamping itu, prinsip keefektifan juga perlu mendapat penekanan. Dengan demikian, prinsip pengelolaan dana pendidikan meliputi transparansi, akuntabilitas, keefektifan, dan efisiensi. Adapun penjelasan masing-masing prinsip tersebut sebagai berikut 1) Transparansi, Transparan berarti ada keterbukaan. Transparan di bidang pengelolaan berarti adanya keterbukaan dalam mengelola suatu kegiatan. Di lembaga pendidikan, bidang pengelolaan keuangan 
yang transparan berarti adanya keterbukaan dalam pengelolaan keuangan lembaga pendidikan, yaitu keterbukaan sumber keuangan dan jumlahnya, rincian penggunaan, dan pertanggungjawabannya yang jelas sehingga memudahkan pihak-pihak yang berkepentingan untuk mengetahuinya. Transparansi keuangan sangat diperlukan dalam rangka meningkatkan dukungan orang tua, masyarakat, dan pemerintah dalam penyelenggaraan seluruh program pendidikan di sekolah. Disamping itu, transparansi dapat menciptakan kepercayaan timbal balik antara pemerintah, masyarakat, orang tua siswa, dan warga sekolah melalui penyediaan informasi dan menjamin kemudahan dalam memperoleh informasi yang akurat dan memadai, 2) Akuntabilitas, Akuntabilitas adalah kondisi seseorang yang dinilai oleh orang lain karena kualitas performansinya dalam menyelesaikan tugas untuk mencapai tujuan yang menjadi tanggung jawabnya. Akuntabilitas di dalam pengelolaan keuangan berarti penggunaan uang sekolah dapat dipertanggungjawabkan sesuai dengan perencanaan yang telah ditetapkan. Berdasarkan perencanaan yang telah ditetapkan dan peraturan yang berlaku, pihak sekolah membelanjakan uang secara bertanggung jawab. Pertanggungjawaban dapat dilakukan kepada orang tua, masyaraka, dan pemerintah. Terdapat tiga pilar utama yang menjadi prasyarat terbangunnya akuntabilitas, yaitu adanya a) transparansi para penyelenggara sekolah/ madrasah dengan menerima masukan dan mengikutsertakan berbagai komponen dalam mengelola sekolah/ madrasah, b) standar kinerja di setiap institusi yang dapat diukur dalam melaksanakan tugas, fungsi dan wewenangnya, dan c) partisipasi untuk saling menciptakan suasana kondusif dalam mengadakan pelayanan masyarakat dengan prosedur yang mudah, biaya yang murah, dan pelayanan yang cepat. 3) Keefektifan, "Efektif" seringkali diartikan sebagai tercapainya tujuan yang telah ditetapkan. Garner (2004) mendefinisikan "efektivitas" lebih dalam lagi karena sebenarnya "efektivitas" tidak hanya sampai pencapaian tujuan, tetapi juga pada kesesuaian kualitas hasil dengan visi lembaga. Effectiveness "characterized by qualitative outcomes". Efektivitas lebih menekankan pada kualitas outcomes. Pengelolaan keuangan dikatakan memenuhi prinsip keefektifan kalau kegiatan yang dilakukan dapat mengatur keuangan untuk membiayai aktivitas dalam rangka mencapai tujuan lembaga yang bersangkutan dan kualitas outcomes-nya sesuai dengan rencana yang telah ditetapkan. 4) Efisiensi, Efisiensi berkaitan dengan kuantitas hasil suatu kegiatan. Efficiency "characterized by quantitative outputs" (Garner, 2004). Efisiensi adalah perbandingan yang terbaik antara masukan (input) dan 
keluaran (out put) atau antara daya dan hasil. Daya yang dimaksud meliputi tenaga, pikiran, waktu, dan biaya. Perbandingan tersebut dapat dilihat dari dua hal: a) Dilihat dari segi penggunaan waktu, tenaga, dan biaya. Kegiatan dapat dikatakan efisien kalau penggunaan waktu, tenaga, dan biaya yang sekecil - kecilnya dapat mencapai hasil yang ditetapkan. b) Dilihat dari segi hasil. Kegiatan dapat dikatakan efisien kalau dengan penggunaan waktu, tenaga dan biaya tertentu memberikan hasil sebanyak - banyaknya, baik kuantitas maupun kualitasnya.

\section{PROSEDUR PENGELOLAAN KEUANGAN SEKOLAH}

Dalam mengelola keuangan, terdapat prosedur pengelolaan yang harus dipenuhi dalam rangka mengelola keuangan sekolah, yakni: penganggaran, pencatatan, pelaporan keuangan sekolah, dan audit keuangan sekolah. Penganggaran adalah penciptaan suatu rencana kegiatan yang dinyatakan dalam ukuran keuangan. Penganggaran memainkan peran penting di dalam perencanaan, pengendalian, dan pembuatan keputusan. Anggaran juga untuk meningkatkan koordinasi dan komunikasi. Unsur-unsur pertimbangan anggaran yakni: 1) Kerangka strategi, prioritas, dan sasaran yang meliputi program belanja public, 2) Kriteria kinerja untuk efisiensi, efektivitas, dan dampak yang secara rutin diamati, 3) Laporan tahunan tentang hasil yang menginformasikan keputusan-keputusan anggaran, 4) Program penganggaran, dengan alokasi berbasis kinerja, dan hasil-hasil yang diharapkan 5) Umpan balik dari pemantauan dan evaluasi untuk membantu penggunaan sumber daya yang dianggarkan dengan lebih efisien.

Mekanisme/prosedur dalam penyusunan anggaran adalah sebagai berikut: 1) Mengidentifikasi kegiatan-kegiatan yang akan dilakukan selama periode anggaran, 2) Mengidentifikasi sumber-sumber yang dinyatakan dalam uang, jasa, dan barang, 3) Semua sumber dinyatakan dalam bentuk uang sebab anggaran pada dasarnya merupakan pernyataan finansial, 4) Memformulasikan anggaran dalam bentuk format yang telah disetujui dan dipergunakan oleh instansi tertentu, 5) Menyusun usulan anggaran untuk memperoleh persetujuan dan pihak yang berwenang, 6) Melakukan revisi usulan anggaran, 7) Persetujuan revisi usulan anggaran, 8) Pengesahan anggaran.

\section{METODE PENELITIAN}

Penelitian ini merupakan penelitian kualitatif, karena dalam mengkaji masalah Peneliti tidak membuktikan atau menolak hipotesis yang dibuat sebelumnya tetapi mengolah data dan menganalisis suatu masalah secara non numerik. Pendekatan 
penelitian yang digunakan dalam penelitian ini adalah pendekatan etnografi. Mantja (2008: 2) menyatakan bahwa etnografi merupakan rekontruksi budaya sekelompok manusia atau hal-hal yang dianggap budaya dalam berbagai kancah kehidupan manusia. Sumber data menggunakan: 1) Peristiwa atau aktivitas, peneliti bisa mengetahui proses bagaimana sesuatu terjadi secara lebih pasti karena menyaksikan sendiri secara langsung. 2) Dokumen, berupa catatan-catatan tertulis yaitu struktur organisasi, RAPBS, dan aktivitas lain nya di SMA Muhammadiyah 1 Palembang. 3) Informan, orang yang dianggap dapat memberikan informasi/ keterangan sesuai dengan masalah yang diteliti.

Teknik pengumpulan data dalam penelitian ini meliputi wawancara, wawancara terhadap informan yang merupakan sumber data dengan topik wawancara yang telah ditetapkan dalam kisi-kisi wawancara. Observasi, observasi yang dilakukan oleh peneliti berpedoman pada kisi- kisi observasi dan checklist observasi. Dokumentasi dan arsip, dokumen dan arsip yang akan digunakan dalam penelitian ini berupa dokumen yang berupa analisis sumber dana sekolah.

\section{HASIL PENELITIAN DAN PEMBAHASAN}

Hasil penelitian yang diperoleh di lapangan melalui wawancara, observasi, dan dokumentasi terkait dengan sumber dana pendidikan meliputi: sumber dana yang diperoleh dari pemerintah pusat melalui pengajuan proposal. Dana yang diperoleh dari pemerintah daerah tidak mencukupi operasional sekolah. Sekolah mengelola dana BOS. Sumber dana yang diperoleh dari orang tua/wali murid ditentukan melalui rapat anggota komite sekolah. Sumber dana yang bersifat sukarela berasal dari masyarakat yang peduli terhadap perkembangan sekolah. Secara bersama-sama menyusun Rancangan Anggaran Pendapatan Belanja Sekolah (RAPBS) untuk menyelaraskan kebutuhan sekolah dan masyarakat dan pengelolaan pendidikan.

Sumber keuangan dan pembiayaan merupakan salah satu sumber daya yang secara langsung menunjang efektifitas dan efisiensi pengelolaan pendidikan. Hal tersebut lebih terasa lag implementasi MBS (Manajemen Berbasis Sekolah), yang menuntut kemampuan sekolah untuk merencanakan, melaksanakan dan mengevaluasi serta mempertanggung jawabkan pengelolaan dana secara transparan kepada masyarakat dan pemerintah.

Adanya dana yang diperoleh dari orang tua dan masyarakat tersebut menunjukkan bahwa masyarakat dan orang tua mempunyai partisipasi terhadap pelaksanaan pendidikan di SMA Muhammadiyah 1 Palembang. Partisipasi masyarakat tersebut tentunya tidak hanya sebatas pada kepedulian terhadap 
kebutuhan dana sekolah melalui keikut sertaan dalam menyusun RAPBS dan sebagai sumber dana, tetapi masyarakat dapat ikut serta menentukan pengembangan kurikulum, dan ikut serta menentukan output sekolah.

Hasil penelitian yang diperoleh dengan teknik wawancara, observasi, dan dokumentasi tentang alokasi dan realisasi pembiayaan pendidikan meliputi: alokasi dana untuk pembiayaan pendidikan secara umum bertujuan untuk memeratakan pendidikan dan dilakukan untuk peningkatan mutu pendidikan. Sratategi pengalokasian pembiayaan pendidikan guna meningkatkan efisiensi penggunaan dana tersebut. Pendekatan efisiensi ini dilakukan dengan tujuan mengantisipasi keterbatasan dalam anggaran, prinsip ini dikenal sebagai prinsip dasar dalam managemen dalam pembiayaan sekolah ketika terjadi keterbatasan dalam sumber daya yang ada mengacu kepada perencanaan yang telah ditetapkan.

Mekanisme yang ditempuh didalam pelaksanaan kegiatan harus benar, efektif dan efisien. Penggunaanan aggaran memperhatikan azas umum pengeluaran sekolah, yaitu pemanfaatan penggunaan uang sekolah minimal harus sama, apabila uang tersebut dipergunakan oleh pengelola sekolah pendidikan dan dilakukan untuk peningkatan mutu pendidikan. Sratategi pengalokasian pembiayaan pendidikan guna meningkatkan efisiensi penggunaan dana tersebut.

Alokasi dana yang dilakukan di SMA Muhammadiyah 1 Palembang, menunjukkan bahwa SMA Muhammadiyah 1 Palembang telah melaksanakan menajemen keuangan yang baik, dimana dalam mengelola keuangan SMA Muhammadiyah 1 Palembang telah melakukan proses - proses perencanaan, pengorganisasian, pengarahan, pengkoordinasian, pengawasan atau pengendalian dan melakukan beberapa kegiatan dengan menetapkan sumber - sumber pendanaan dan alokasi pendanaan yang merupakan implementasi dari pemanfaatan pendanaan.

Hasil penelitian yang diperoleh dengan teknik wawancara, observasi, dan dokumentasi tentang pertanggungjawaban dana pendidikan meliputi: Kepala sekolah sebagai pengguna dana, diwajibkan menyusun Surat Pertanggungjawaban (SPJ) keuangan kepada sumber dana, baik pemerintah pusat, provinsi maupun kota dan orang tua murid. Khusus pelaporan kepada orang tua murid dilakukan sekolah melalui papan pengumuman. Pelaporan disertai dengan kelengkapan dan berbagai data pendukung, yang berupa bukti pengeluaran, dan perincian pengeluaran keuangan.

Laporan keuangan dibuat oleh bendahara diketahui oleh kepala sekolah dan komite 
sekolah setiap bulan sekali. Selain laporan bulanan kepala sekolah diwajibkan membuat laporan triwulan tiga bulan sekali dan disampaikan kepada pemerinta, orang tua melalui komite sekolah, dan melakukan evaluasi tentang realisasi penggunaan dana sekolah, format pelaporan sudah ditentukan oleh pemerintah. Penyampaian laporan bulanan kepada masyarakat disampaikan dengan cara ditempel pada papan pengmuman, sehingga setiap masyarakat, melalui siswa dan komite sekolah dapat membaca laporan keuangan.

\section{KESIMPULAN}

Sumber pendapatan di SMA Muhammadiyah 1 Palembang tercantum dalam RAPBS. Sumber pendapatan yang diperoleh dari pemerintah Pusat melalui APBN, Pemerintah Provinsi melalui APBD Provinsi, dan APBD Kota Palembang. Sumber pendapatan dari pemerintah berupa BOS yang diperoleh melalui pengajuan proposal. Selain dari pemerintah, masyarakat dan orang tua murid mempunyai partisipasi yang besar terhadap pendanaan sekolah dengan cara memberikan dukungan dana untuk pelaksanaan program - program sekolah.

Alokasi dana untuk pembiayaan pendidikan secara umum bertujuan untuk memeratakan pendidikan dan dilakukan untuk peningkatan mutu pendidikan. Pengalokasian dana dilakukan secara efisiensi yaitu menggunakan anggaran sesuai dengan RAPBS yang telah ditetapkan untuk mengantisipasi keterbatasan dalam anggaran, mekanisme yang ditempuh di dalam pelaksanaan kegiatan dilakukan dengan benar, efektif dan efisien.

Pertanggungjawaban keuangan sekolah dibuat oleh bendahara dan Kepala sekolah diketahui oleh komite sekolah setiapbulan, disertai dengan kelengkapan dan berbagai data pendukung, yang berupa bukti pengeluaran, dan perincian pengeluaran keuangan. Selain dalam bentuk laporan bulanan, pertanggung jawaban keuangan sekolah dibuat secara berkala dalam bentuk laporan triwulan dan lapaoran tahunan. Penyampaian laporan bulanan kepada masyarakat disampaikan dengan cara ditempel pada papan pengumuman, sehingga setiap masyarakat, melalui siswa dan komite sekolah dapat membaca laporan keuangan.

\section{DAFTAR PUSTAKA}

Campbell, R. F., Bridges, E. M., dan Nystrand, R. O. (1983). Introduction to Educational Administration. Boston: Allyn an Bacon, Inc.

Departemen Pendidikan Nasional, Direktorat Jenderal Peningkatan Mutu Pendidik dan Tenaga Kependidikan, Direktorat Tenaga Kependidikan. (2007). Manajemen Keuangan Sekolah.

Gunawan Imam. (2017). Manejemen Keuangan Sekolah. http://masimamgun. blogspot.co.id/2009/04/manajeman- 
keuangan-sekolah.html. Diakses 26 Desember 2017 jam 14.30

Kementrian Pendidikan dan Kebudayaan LPPKS Indonesia. (2017). Pengelolaan Keuangan Sekolah/ Madrasah. https://katresna72.files.wordpress.com/2 011/06/3-pengelolaan-kuangansekolah.pdf. Diakses 26 Desember 2017 jam 13.30

Kristiawan, M. Safitri, D. Rena L. (2017). Manajemen Pendidikan. Yogyakarta: Deepublish.

Lipham SM. (1985). The Principleship: Concepts, Competencies and Cosos. London: Longmart
Rosita, Tita. (2011). Pengelolaan Keuangan Sekolah. Surakarta: Universitas Terbuka

Raja Jempol Blog. (2013). Manejemen Keuangan Sekolah. http://rajajempol.blogspot.co.id/2013/05/manajem en-keuangan-sekolah.html. Diakses tanggal 27 Desember 2016 jam 08.00

Undang-Undang Nomor 20 Tahun 2003 tentang Sistem Pendidikan Nasional

Peraturan Pemerintah No 19 Tahun 2005 tentang Standar Nasional Pendidikan

Peraturan Gubernur Sumatera Selatan Nomor 31 Tahun 2009 Tentang Pedoman Penyelenggaraan Program Sekolah Gratis Di Propinsi Sumatera Selatan 